\title{
A study on the job satisfaction levels of Pharmacists working in a community pharmacy set-up at northern part of Kerala.
}

\author{
Mr. Kiron.S.S, Dr. Premaletha.K, Mr. P.L.Rajagopal, Mrs. Saritha M \\ 1. Dr. Premaletha.K, Prof and HOD, Dept. of Pharmaceutics, Academy of Pharmaceutical Sciences, Pariyaram \\ Medical College, Kannur, Kerala. \\ 2. Mr. Kiron.S.S, Asst. Professor, Dept. of Pharmacy Practice, Academy of Pharmaceutical Sciences, Pariyaram \\ Medical College, Kannur, Kerala. \\ 3. Mr. P.L.Rajagopal, Asst. Professor, Dept. of Pharmacognosy, Academy of Pharmaceutical Sciences, Pariyaram \\ Medical College, Kannur, Kerala \\ 4. Mrs. Saritha M, Dept.of Pharmacy Practice, Crescent B.Pharm College, Payangadi, Kannur, Kerala.
}

\begin{abstract}
:
Job satisfaction is a very important contributing factor for person's productivity and motivation. A Cross sectional survey was conducted in Kannur district. A multiple choice questionnaire was prepared and used to obtain the data. Of the 53 pharmacies, $78 \%$ of pharmacists working in these regions had D. Pharm qualification and $10 \%$ were B.Pharm graduates. $39.6 \%$ of the study population is under stress of the profession and they worries about the work issues even when they are at home. $60.3 \%$ receives support from their supervisors. $1.8 \%$ of the study population considers that the work activities are personally meaningless. A very few population still thinks that their job as a community pharmacist is not a professional position and they does not receive a professional value from other people of the society. In summary, the pharmacists were satisfied with their interpersonal relations as measured in the subscales, patient interaction, coworkers and supervision.
\end{abstract}

Keywords: work load, worry, professional value.

\section{INTRODUCTION:}

Pharmacy is the health profession that links the health sciences with the basic sciences; it is committed to ensuring the safe $\&$ effective use of medication. ${ }^{1}$ Community pharmacy is a pharmacy services established in a community to the needs of the society for their drug products, health care items and related materials. It provides the pharmaceutical services required for the health care of the people in general and patents in particular. Community pharmacy aims to offer health care to group of people with emphasis on prescriptions and related matters including medications commonly used in homes. ${ }^{2}$

Pharmacists are experiencing increased demand for their services because of the increase in the age of the population and the consequent increased use of prescription drugs. Attitudes toward work encompass many things as role conflict, role ambiguity, role overload, work-home conflict, job stress, and job satisfaction. ${ }^{3}$ Job satisfaction is a very important contributing factor for persons productivity and motivation. ${ }^{4} \mathrm{Job}$ satisfaction measures were of two general types, facet-free measures, which assess overall satisfaction, and facet-specific measures, which gauge satisfaction with respect to a specific aspect of the job. ${ }^{5}$ Patrick Hardigan et al investigated the effect of gender, ethnicity, practice site and income among practicing pharmacists. The findings are older, higher wage earning pharmacists working at independent practice sites experiences the greatest amount of job satisfaction. ${ }^{6}$

\section{MATERIALS AND METHODS:}

The aim of this research was to measure the job satisfaction levels of Pharmacists working in a community pharmacy set-up. A Cross sectional survey was conducted in Kannur district from April 2011 - September 2011. All pharmacists working in community pharmacists were included for present study. Ayurvedic and homeopathic pharmacists were excluded. A multiple choice questionnaire (Table no: 1) was prepared and used to obtain the data. The questionnaire include: Demographic status, Qualification; Job satisfaction parameters and Stressful aspects of the work for the community pharmacist. 


\section{RESULTS AND DISCUSSION:}

Out of the 53 study population $64 \%$ of the pharmacists were found to be males and the rest females. Demography of pharmacist shows that $41 \%$ fall under age group of 30-39. Of the 53 pharmacies, $78 \%$ of pharmacists working in these regions had D. Pharm qualification and $10 \%$ were B.Pharm graduates. It was quite surprising that none of the pharmacists had M.Pharm qualification in these regions. The experience of pharmacist in the study region is given in figure-1. Subal Chandra Basak $(2010)^{7}$ also observed that community pharmacies were managed by less qualified (compared too many other countries) diploma trained pharmacists.

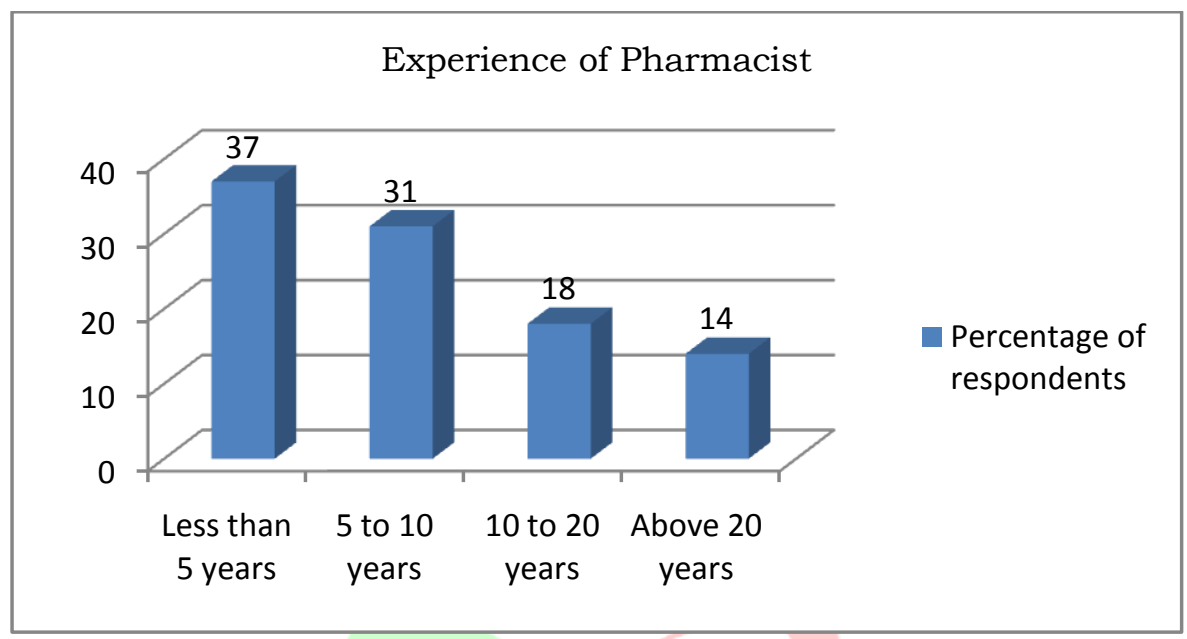

Figure - 1 Experience of pharmacist

Among the study population half of them received adequate training to do their job well. Majority of the study population (Table No: 2 and 3) feels that they are valued by their pharmacy and they consider their job as a valuable profession. 39.6\% of the study population is under stress of the profession and they worries about the work issues even when they are at home. Out of the study population $60.3 \%$ receives support from their supervisors. A very few population still thinks that their job as a community pharmacist is not a professional position and they does not receive a professional value from other people of the society. $1.8 \%$ of the study population considers that the work activities are personally meaningless. Many of the community pharmacists are overwhelmed by the responsibilities at their work place. Out of the study population half of them blames about their inadequate facilities like equipment and space to get done their job. $35.8 \%$ of the study population are not keeping themselves up to date with current clinical and research practices. Very few try hard to come up with current clinical trends. Very few thinks that they are responsible for relieving emotional distress of the patient and they do not think that they have responsibilities to build quality work atmosphere for other staff. Half of the study population feels that they are poorly paid for the job. Majority of the community pharmacist feels that their skills and experience are being put to their best use. 
IOSR Journal of Pharmacy

Vol. 2, Issue 3, May-June, 2012, pp.485-490

Table no 2:- percentage Respondents in Job satisfaction parameters:

\begin{tabular}{|l|l|l|l|l|l|l|l|}
\hline $\begin{array}{l}\text { S1 } \\
\mathrm{N} \\
\text { : }\end{array}$ & QUESTIONS Agree & $\begin{array}{l}\text { Strongly } \\
\text { agree }\end{array}$ & $\begin{array}{l}\text { Some } \\
\text { what } \\
\text { agree }\end{array}$ & $\begin{array}{l}\text { Some } \\
\text { what } \\
\text { disagree }\end{array}$ & Disagree & Disagree strongly \\
\hline 1 & $\begin{array}{l}\text { I had a good idea of what this } \\
\text { position involved before I began }\end{array}$ & 47.16 & 11.3 & 37.7 & NA & NA & NA \\
\hline 2 & I feel that I am valued by this Pharmacy & 56.6 & 35.8 & 7.5 & NA & NA & NA \\
\hline 3 & $\begin{array}{l}\text { I receive adequate training to do my job } \\
\text { well }\end{array}$ & 52.8 & 20.7 & 22.6 & 1.8 & 1.8 & NA \\
\hline 4 & $\begin{array}{l}\text { I feel overwhelmed by my } \\
\text { responsibilities at work }\end{array}$ & 35.8 & 30.1 & 30.1 & NA & 9.4 & NA \\
\hline 5 & $\begin{array}{l}\text { My work activities are personally } \\
\text { meaningful to me }\end{array}$ & 47.16 & 43.3 & 7.5 & NA & 1.8 & NA \\
\hline 6 & $\begin{array}{l}\text { Other people view my job as a valuable } \\
\text { profession }\end{array}$ & 49.05 & 28.3 & 15.09 & 3.77 & 3.77 & $\mathrm{NA}$ \\
\hline 7 & $\begin{array}{l}\text { I am satisfied with the way that this } \\
\text { Pharmacy is managed }\end{array}$ & 56.6 & 28.3 & 11.3 & $\mathrm{NA}$ & 3.77 & $\mathrm{NA}$ \\
\hline 8 & $\begin{array}{l}\text { I am confident of my abilities to succeed } \\
\text { at my work }\end{array}$ & 62.26 & 32.07 & 5.6 & $\mathrm{NA}$ & $\mathrm{NA}$ & $\mathrm{NA}$ \\
\hline 9 & $\begin{array}{l}\text { I regularly think/worry about work } \\
\text { issues when I am at hom }\end{array}$ & 18.8 & 7.5 & 39.6 & 5.6 & 18.8 & 9.4 \\
\hline 10 & $\begin{array}{l}\text { I believe that my position at work is a } \\
\text { professional position }\end{array}$ & 56.6 & 37.7 & 1.8 & 3.77 & $\mathrm{NA}$ & $\mathrm{NA}$ \\
\hline 11 & I am satisfied with my income & 26.4 & 3.77 & 30.1 & 15.09 & 11.3 & 13.2 \\
\hline 12 & $\begin{array}{l}\text { I have mastered the skills necessary to } \\
\text { perform my work }\end{array}$ & 54.7 & 9.4 & 30.1 & 3.77 & 1.8 & $\mathrm{NA}$ \\
\hline 13 & $\begin{array}{l}\text { I make a difference in lives of other } \\
\text { people }\end{array}$ & 26.4 & 3.77 & 47.16 & 1.8 & 15.09 & 5.6 \\
\hline 14 & $\begin{array}{l}\text { I have ample opportunities for } \\
\text { advancement in this profession }\end{array}$ & 45.2 & 11.3 & 28.3 & 3.7 & 11.3 & $\mathrm{NA}$ \\
\hline 15 & $\begin{array}{l}\text { I believe that my supervisors care deeply } \\
\text { for me and for our clients }\end{array}$ & 62.2 & 18.8 & 18.8 & $\mathrm{NA}$ & $\mathrm{NA}$ & $\mathrm{NA}$ \\
\hline 16 & $\begin{array}{l}\text { This job adds significant pressure and } \\
\text { anxiety to my life }\end{array}$ & 13.2 & 9.4 & 39.6 & 7.5 & 20.7 & 9.4 \\
\hline 17 & $\begin{array}{l}\text { I am satisfied with the benefits offered to } \\
\text { me through this job }\end{array}$ & 60.3 & 13.2 & 18.8 & 3.77 & 3.77 & $\mathrm{NA}$ \\
\hline 18 & $\begin{array}{l}\text { I receive adequate support from my } \\
\text { supervisors }\end{array}$ & 60.3 & 16.9 & 20.7 & $\mathrm{NA}$ & 1.8 & $\mathrm{NA}$ \\
\hline
\end{tabular}


Table No: - 3 percentage Respondents in Stressful aspects of the work

\begin{tabular}{|l|l|l|l|l|l|}
\hline $\begin{array}{l}\text { S1 } \\
\text { no: }\end{array}$ & QUESTIONS & 0 & A Little & Quit A bit & A Lot \\
\hline 1 & $\begin{array}{l}\text { Being involved with the physical suffering of } \\
\text { patients }\end{array}$ & $18(33.9 \%)$ & $16(30.18 \%)$ & $11(20.75 \%)$ & $8(15.09 \%)$ \\
\hline $\begin{array}{l}\text { Encountering difficulties in relationship with } \\
\text { junior medical staff }\end{array}$ & $26(49.05 \%)$ & $18(33.96 \%)$ & $7(13.20 \%)$ & $2(3.77 \%)$ \\
\hline 3 & $\begin{array}{l}\text { Disruption of your home life through } \\
\text { spending long hours at work }\end{array}$ & $22(41.5 \%)$ & $17(32.07 \%)$ & $5(9.43 \%)$ & $9(16.98 \%)$ \\
\hline 4 & $\begin{array}{l}\text { Having inadequate facilities (e.g. equipment } \\
\text { space )to do your job properly }\end{array}$ & $28(52.83 \%)$ & $18(33.96 \%)$ & $6(11.32 \%)$ & $2(3.77 \%)$ \\
\hline 5 & $\begin{array}{l}\text { Having to deal with distressed, angry or } \\
\text { blaming relatives }\end{array}$ & $30(56.60 \%)$ & $10(18.86 \%)$ & $9(16.98 \%)$ & $4(7.5 \%)$ \\
\hline 6 & $\begin{array}{l}\text { Keeping up to date with current clinical and } \\
\text { research practices }\end{array}$ & $19(35.84 \%)$ & $17(32.07 \%)$ & $10(18.86 \%)$ & $6(11.32 \%)$ \\
\hline 7 & $\begin{array}{l}\text { Being responsible for the quality of work of } \\
\text { other staff }\end{array}$ & $14(26.41 \%)$ & $23(43.39 \%)$ & $6(11.32 \%)$ & $10(18.8 \%)$ \\
\hline 8 & $\begin{array}{l}\text { Being involve with the emotional distress of } \\
\text { patients }\end{array}$ & $14(26.41 \%)$ & $23(43.39 \%)$ & $7(13.20 \%)$ & $9(16.98 \%)$ \\
\hline 9 & $\begin{array}{l}\text { Having too great an overall volume of work } \\
\text { Feeling you are poorly paid for the job you } \\
\text { do }\end{array}$ & $13(24.52 \%)$ & $25(47.16 \%)$ & $7(13.20 \%)$ & $8(15.09 \%)$ \\
\hline 11 & $\begin{array}{l}\text { Encountering difficulties in relationships with } \\
\text { managers }\end{array}$ & $28(52.83 \%)$ & $14(26.41 \%)$ & $6(11.32 \% \%)$ & $5(9.43 \%)$ \\
\hline 12 & $\begin{array}{l}\text { Having conflicting demands on your time } \\
\text { (e.g. } \\
\text { /management/research/college) }\end{array}$ & $22(41.50 \%)$ & $19(35.84 \%)$ & $7(13.20 \%)$ & $5(9.43 \%)$ \\
\hline 13 & $\begin{array}{l}\text { Feeling that your accumulated skills and } \\
\text { expertise are not being put to their best use }\end{array}$ & $22(41.50 \%)$ & $14(26.41 \%)$ & $8(15.09 \%)$ & $9(16.98 \%)$ \\
\hline
\end{tabular}

In summary, pharmacists were satisfied with their interpersonal relations as measured in the subscales, patient interaction, coworkers and supervision. It was also noted that the employees were relatively satisfied with their work. There was a low satisfaction with pay and promotion amongst the pharmacists. Most respondents felt they would leave the public service because of the compensation packages, shortage of staff which in turn leads to excessive workload. These group of respondents also mentioned that they get pleasure from the working hours in the public service and the relationship that exists with patients and colleagues. The work-life conflict was reported by some of the respondents saying they would like to work sessions or flexible hours so that they have a sufficient amount time with their families. Also with work stress, the respondents indicated that because they get very tired at the end of the day that they cannot give attention to their families when they get home. These variables are important as work stress can have health implications on the employees.

Limitations Of The Study: Several limitations of this study should be addressed to highlight sources of bias. The main limitation of this study was that the population size was small and hence the findings of this research cannot be extrapolated to represent the perceptions and level of job satisfaction of pharmacists in Kannur. Although the study suggests relatively high satisfaction scores in this group of pharmacists, it would be instructive to determine the applicability of the job satisfaction measure and to explore the satisfaction levels of pharmacists in a wide range of roles and sectors, to determine relative levels of satisfaction. 


\section{REFERENCES}

1. Jaiswal NR .Social status of retail Pharmacist In India ; The Indian Journal of Hospital Pharmacy ,Nov-Dec 2006; XLIII6:175-179.

2. Foppe JW Van Will, Th.FJ Tromp J,McElnay. Community Pharmacy around the world. IPJ. 2001; 15(1): 7-22.

3. David A. Mott, William R. Doucette, Caroline A. Gaither, Craig A. Pedersen, and Jon C. Schommer. Pharmacists' Attitudes Toward Worklife: Results From a National Survey of Pharmacists. J Am Pharm Assoc. 2004; 44(3).Available from: http://www.medscape.com/viewarticle/479832

4. SivakamiJanahiraman, and Thomas Paraidathathu. Job Satisfaction among Malaysian Pharmacists. Jurnal Sains Kesihatan Malaysia. 2007; 5(2):5 79-90.

5. P.A Robers .Job satisfaction that is relevant to pharmacists. American Journal of Hospital Pharmacy. 40(3): 391-399.Availble from: http://ajhp.org/content/40/3/391.abstract

6. Patrick Hardigan, Manuel Carvajal. Job Satisfaction among Practicing Pharmacists: A Rasch Analysis. The Internet Journal of Allied Health Sciences and Practice, 2007; 5(4): 1-9.

7. Subal Chandra Basak, Dondeti Sathyanarayana. Evaluating medicines dispensing patterns at private community pharmacies in Tamilnadu, India. Southern Med Review.2010 Oct; 3(2):27-31.

Table No 1: Questionnaire to Community Pharmacist

Job Satisfaction Questionnaire

1. Name of pharmacy where you work:

3. Today's Date:

4. How many years have you worked for this Pharmacy? (Circle one)

$<1123456789101112131415+$

5. How many hours (on average) do you work per week?

6. Do you have another job in addition to this one (circle answer)? YES NO

7. If yes, how many hours do you work at your other job per week?

For the Following Questions, Please Circle the Answer that Best Describes Your Views:

8. I had a good idea of what this position involved before I began.

Agree, Strongly Agree, Somewhat Agree, Somewhat Disagree, Disagree, Disagree Strongly

9. I feel that I am valued by this Pharmacy.

Agree, Strongly Agree, Somewhat Agree, Somewhat Disagree, Disagree, Disagree Strongly

10. I receive adequate training to do my job well.

Agree, Strongly Agree, Somewhat Agree, Somewhat Disagree, Disagree, Disagree, Strongly

11. I feel overwhelmed by my responsibilities at work.

Agree, Strongly Agree, Somewhat Agree, Somewhat Disagree, Disagree, Disagree Strongly

12. My work activities are personally meaningful to me.

Agree, Strongly Agree, Somewhat Agree, Somewhat Disagree, Disagree, Disagree Strongly 13. Other people view my job as a valuable profession.

Agree, Strongly Agree, Somewhat Agree, Somewhat Disagree, Disagree, Disagree Strongly

14. I am satisfied with the way that this Pharmacy is managed.

Agree, Strongly Agree, Somewhat Agree, Somewhat Disagree, Disagree, Disagree Strongly

15. I am confident of my abilities to succeed at my work.

Agree, Strongly Agree, Somewhat Agree, Somewhat Disagree, Disagree, Disagree Strongly

16. I regularly think/worry about work issues when I am at home.

Agree, Strongly Agree, Somewhat Agree, Somewhat Disagree, Disagree, Disagree Strongly

19. I believe that my position at work is a professional position.

Agree, Strongly Agree, Somewhat Agree, Somewhat Disagree, Disagree, Disagree Strongly

18. I am satisfied with my income.

Agree, Strongly Agree, Somewhat Agree, Somewhat Disagree, Disagree, Disagree Strongly

19. I have mastered the skills necessary to perform my work.

Agree, Strongly Agree, Somewhat Agree, Somewhat Disagree, Disagree, Disagree Strongly

20. I make a difference in the lives of other people.

Agree, Strongly Agree, Somewhat Agree, Somewhat Disagree, Disagree, Disagree Strongly

21. I have ample opportunities for advancement in this profession.

Agree, Strongly Agree, Somewhat Agree, Somewhat Disagree, Disagree, Disagree Strongly

22. I believe that my supervisors care deeply for me and for our clients.

Agree, Strongly Agree, Somewhat Agree, Somewhat Disagree, Disagree, Disagree Strongly

23. This job adds significant pressure and anxiety to my life.

Agree, Strongly Agree, Somewhat Agree, Somewhat Disagree, Disagree, Disagree Strongly 
24. I am satisfied with the benefits offered to me through this job.

Agree, Strongly Agree, Somewhat Agree, Somewhat Disagree, Disagree, Disagree Strongly

25. I receive adequate support from my supervisors.

Agree, Strongly Agree, Somewhat Agree, Somewhat Disagree, Disagree, Disagree Strongly

Stressful aspects of your work

To what extent have the following factors contributed to any stress you have experienced in your job in the past few months? Please rate each factor by circling the relevant number on the 0 to 3 scale. If not applicable, please rate ' 0 '.

\section{Extent contributes to stress}

Not at all -0

A Little - 1

Quite A bit - 2

A Lot -3

1. Being involved with the physical suffering of patients 0123

2. Encountering difficulties in relationships with junior medical staff $\begin{array}{lll}\mathbf{1} & \mathbf{2} & 3\end{array}$

3. Disruption of your home life through spending long hours at work 0123

4. Having inadequate facilities (e.g. equipment, space) to do your job properly $\mathbf{0} 123$

5. Having to deal with distressed, angry or blaming relatives 0123

6. Keeping up to date with current clinical and research practices 0123

7. Being responsible for the quality of the work of other staff 0123

8. Being involved with the emotional distress of patients 0123

9.Having too great an overall volume of work 0123

10. Feeling you are poorly paid for the job you do $\mathbf{0} 123$

11. Encountering difficulties in relationships with managers 0123

12. Having conflicting demands on your time (e.g. patient care/management/research/College)

0123

13. Feeling that your accumulated skills and expertise are not being put to their best use

0123

Any Additional Comments? (Feel free to explain the reasons behind your answers to these

questions and/or tell us what specific things could be done to enhance your job satisfaction). 